\title{
Study and diachronic analysis of forest cover changes of Belezma-Algeria
}

\author{
Amina Barbache ${ }^{A^{*}}$, Yassine Beghami ${ }^{\mathrm{B}}$, Hassen Benmessaoud ${ }^{\mathrm{C}}$ \\ Received: September 07, 2018 | Revised: December 20, 2018 | Accepted: December 21, 2018 \\ DOI: ????????
}

\begin{abstract}
This study aims to analyze the changes of forest cover in the region of Belezma-BATNA in North Algeria, during a period of 31 years (1986 to 2017), based on the use of remote sensing data (diachronic analysis of satellite images Landsat) by calculating indices (NDVI and NDWI). The results revealed significant changes during this period. Regressive changes in vegetation cover, particularly between 2000 and 2017. This degradation is mainly located in the southern and southeastern part of the Belezma forest resulting from several natural and anthropogenic factors. It can be considered that drought is one of the main causes causing the regressive change of forest during this period with other factors that promote this degradation such as overgrazing, fire, phytosanitary problems (caterpillar processionary), etc.
\end{abstract}

Keywords: Remote sensing; change detection; analysis of forest; forest cover; Diachronic analysis

\section{Introduction}

The Mediterranean forests constitute a fragile natural environment, deeply disturbed by multiple uses. Aggressions are variable depending on the human demography and needs. These determine the progression or regression phases of the forest surface (Quézel \& Barbéro 1990).

Forest biodiversity is declining in most of the forest regions of Algeria. In addition to the natural vulnerability that characterizes the Mediterranean forests and the formations sub forestry, the Algerian forest continues to undergo various pressures and repeated significantly reducing its vegetation potentials, water and soil (Chenouf et al., 2009).

Earth observation technologies play a major role in the study, modeling and monitoring of environmental phenomena, at variable spatial and temporal scales, and on an objective, exhaustive and permanent basis. These technologies thus pave the way for the es- tablishment of early warning systems and enable policy-makers and decision-makers to define appropriate strategies in the context of sustainable development (Gerard et al., 2014).

Remote sensing allows us to monitor our environment on wide expanses, to make comparisons in time and space in order to better understand the functioning of ecosystems (Tidjani et al., 2009). For this we chose a remote sensing methods; the diachronic analysis of data to multi-date satellite imagery to inform us on the signs of the degradation of the environment. Therefore, the main objective is to show the potential for the use of remote sensing and GIS for the characterization of state of the forest cover and its spatio-temporal evolution.

The analysis of the landuse dynamic was made based on the Interpretation of vegetation indices calculated from satellite images multidates (1986-2000 and 2017).

\footnotetext{
A Department of Ecology and Environment, Faculty of Nature and Life Sciences, University of Batna 02, Batna, Algeria

${ }^{B}$ Institute of Veterinary Sciences and Agricultural Sciences, University of Batna 01, Batna, Algeria

c Department of Agricultural sciences, University of Batna 01, Batna, Algeria

* Corresponding author: Amina Barbache; e-mail: aminab1990@hotmail.com
} 


\section{Materials and methods}

\section{Study area}

The study has been carried out in the forest of Belezma located on the North-Est of Algeria in $\left(35^{\circ} 30^{\prime}\right.$ and $35^{\circ}$ $45^{\prime} \mathrm{N} ; 5^{\circ} 45^{\prime}$ et $\left.6^{\circ} 20^{\prime} \mathrm{E}\right)$, With an area of 34396,4 hectares and expands over the following common: Fesdis, Batna, Oued-Chaaba, Merouana, Oued el-ma, Hidoussa, Seriana, Djerma and Taxlent (Fig.1).
In order to compare our data from the NDVI and the NDWI with the field, a sampling that consisted in carrying out phytoecological surveys where a number of environmental factors have been taken into account.

The diagram below illustrates the major steps adopted for the development of the vegetation dynamics.

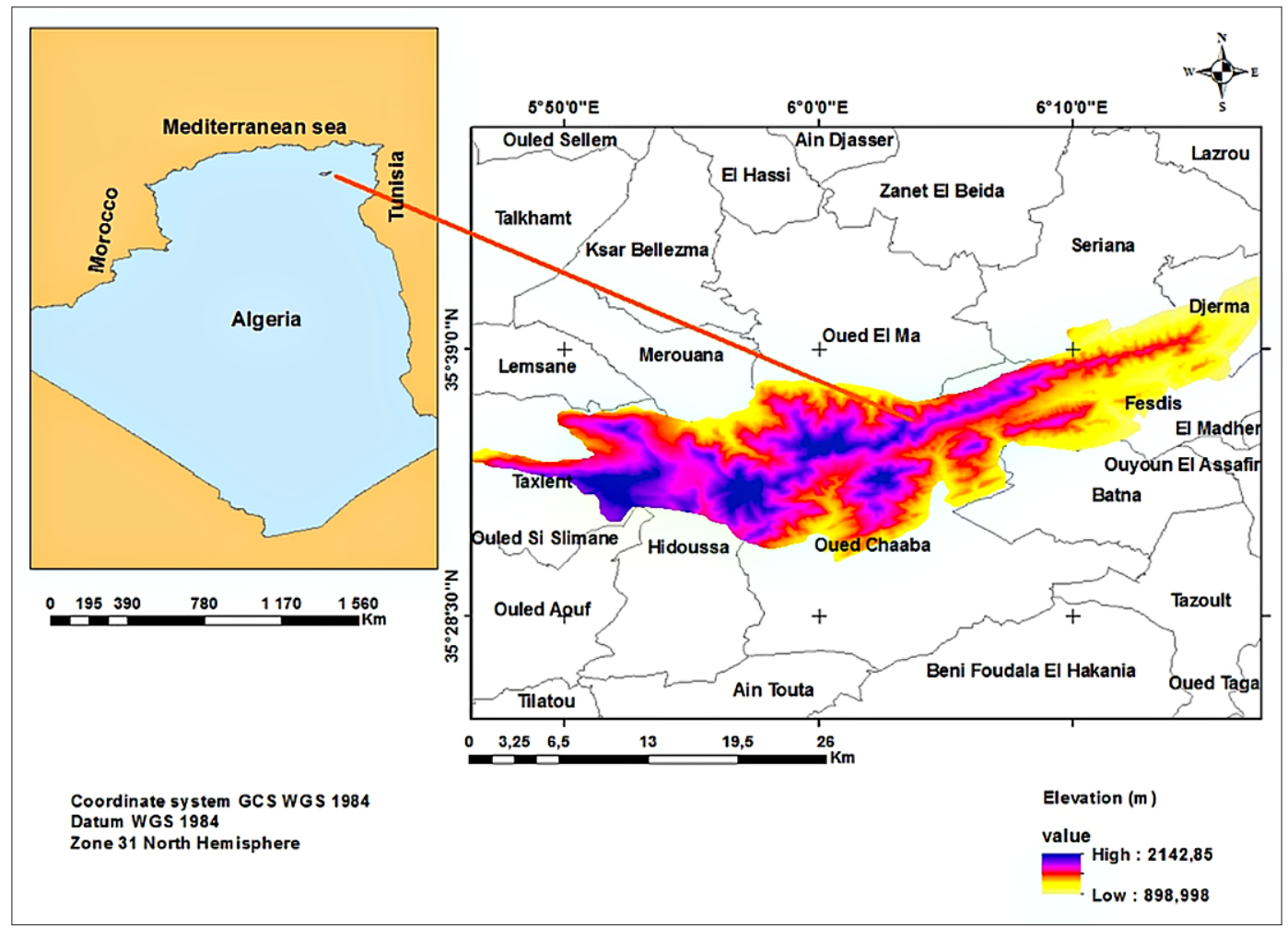

Figure 1. Geographic localization of the study area

The Belezma is formed of a series of folds more or less in parallel. In the East the first fold is constituted by three mountains with the relief very steep: Touggour (2091 meters a.s.l), Boumerzoug (1778 meters a.s.l), and Kasserou. The second fold is consisted the chain of Chellala who prolongs in North East by Maaguel and in South-west by Bordjem and Tichao (2138 meters a.s.l). In the West by Tichao and above Merouana draws up the fold of Refaa (2178 meters a.s.l) (Abdessemed, 1981). The climate of the area of study is of the Mediterranean type, the climate analysis shows that this area overlaps on two floors bioclimatic semi-arid and subhumid at cold winter.

\section{Methods}

The followed methodology in this study is a geomatic approach for the extraction of the geographical information based on the calculation of vegetation indices (NDVI and NDWI) from Satellite Images of the three dates (1986, 2000 and 2017).

\section{Geometric corrections}

They are intended to correct the spatial image of the systematic deformations due to the shooting in order to make it superimposable on a map or another image. The satellite images used were georeferenced in the projection system (Latitude / Longitude, Type WGS 84).

\section{Choice of the color composite and application of a mask of the study area}

The analysis of the spectral signature of the different types of the landuse is an important step for choosing the right channel (Bensaid, 2006). We used the false color composite (band: 4-3-2 for Landsat 5 and 7 and band: 5-4-3 for Landsat 8). It associates the near-infrared, red and green band of the sensor with the red green and blue colors of the screen. This composite is very effective for analyzing vegetation. It exploits the peculiarity of the spectrum reflected by plants, which has a significant "peak" in the near infrared. 


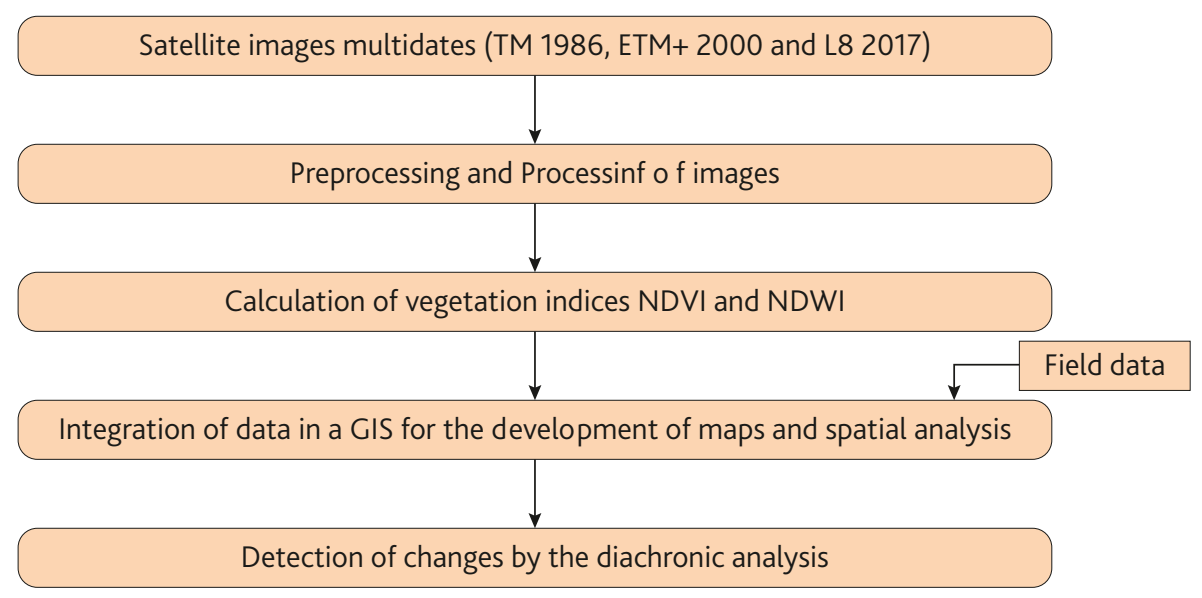

Figure 2. Methodology Chart

On an image in "false infrared colors", the vegetation which has a strong photosynthetic activity appears in bright red (peak of the near infrared), the water appears practically in black (this material absorbs practically all the wavelengths) and mineral surfaces (bare ground, concrete), appear in shades of blue to white. The purpose of a mask is to eliminate areas of the image that could affect the results. of this work, we applied a mask to determine the study area that represents the limits of the Belezma forest.

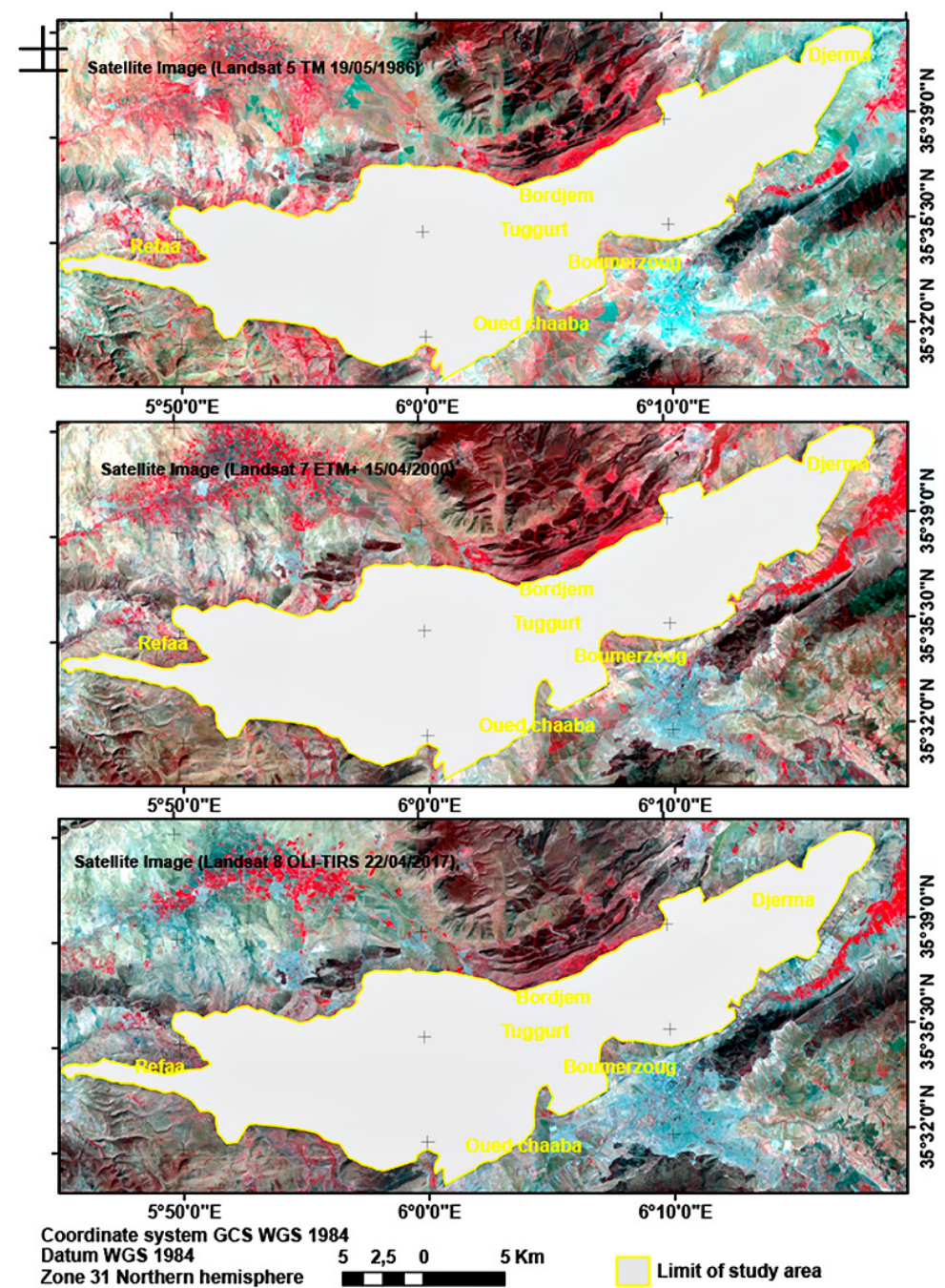

Figure 3. The color composite (band: 4-3-2 for Landsat 5 and 7 and band: 5-4-3 for Landsat 8) 


\section{Calculation of indices}

The indices are obtained by a mathematical combination of spectral bands of the image. They are useful to highlight or enhance certain types of landuses. There are several types of indices; we will calculate two indices of vegetation to extract the changes in the forest cover between the different dates.

\section{Calculation of Normalized Difference Vegetation Index (NDVI)}

The vegetation index is linked to the activity of the plant cover: Leaf pigment strongly absorbs radiation in the red (R) while the spongy parenchyma reflects a large part of the near infrared radiation (NIR). As well in the development phase of a covered, the biomass and the quantities of pigments are increasing, which leads to an increase in the near infrared and a decline in the red. The reverse occurs at the end of the vegetative cycle. Several indices, proportional to a chlorophyll activity active; have thus been developed among which one of the most known is:

NDVI $=($ NIR - R $) /($ NIR + R $)$ whose values vary between-1 and +1 (Deshayes and Maurel, 1991).

We calculate the NDVI, because it is a good indicator of the biomass and the health of the plant. It is used to discriminate the bare soil and plant surfaces.

\section{Normalized Water Difference Index (NDWI)}

In 1996, Gao proposed this index for the detection of water contained in vegetation.

The normalized difference water index (NDWI), is proposed for remote sensing of vegetation liquid water from space. NDWI is defined as ( $\mathrm{p}(0.86 \mathrm{um})-$ $\mathrm{p}(1.24 u m)) /(\mathrm{p}(0.86 u m)+\mathrm{p}(1.24 u m))$, where $\mathrm{p}$ represents the radiance in reflectance units. Both the o.86- um and the 1.24- um channels are located in the high reflectance plateau of vegetation canopies. They sense simi- lar depths through vegetation canopies. Absorption by vegetation liquid water near $0.86 \mathrm{um}$ is negligible. Weak liquid absorption at $1.24 \mathrm{um}$ is present. Canopy scattering enhances the water absorption. As a result, NDWI is sensitive to changes in liquid water content of vegetation canopies. Atmospheric aerosol scattering effects in the 0.86-1.24 um regions are weak. NDWI is less sensitive to atmospheric effects than NDVI; NDWI does not remove completely the background soil reflectance effects, similar to NDVI. Because the information about vegetation canopies contained in the 1.24- um channel is very different from that contained in the red channel near $0.66 \mathrm{um}$, NDWI should be considered as an independent vegetation index. It is complementary to, not a substitute for NDVI (Gao, 1996).

\section{Field data (Phytoecological records)}

Phytoecological surveys were carried out on the ground at different stations in the forest, and the surveys took into account the period of optimum vegetation development. The vegetative period begins at the beginning of March and around the middle of this month in the mountains and goes until the end of October (Fall) and mid-October in (mountain) (Sahli, 2004). We have realized them in the period of Aprilbeginning of June.

Subjective sampling was adopted in this study. According to Gounot (1969), it is the simplest and most intuitive form of sampling. The researcher chooses areas that seem to him, particularly homogeneous and representative according to his experience or his subjective choice.

At each floristic survey, we noted geographic coordinates, aspect, elevation, slope, litter cover, human activities (pasture), and a list of all species recorded. Then we made a table that allows us to combine the field results with those of remote sensing which are the indices calculated from the satellite images (NDVI and NDWI) to make the analysis.

\section{Results and discussion}

\section{Normalized Difference Vegetation Index (NDVI)}

The NDVI results are maps showing a growing gradient of plant activity with values ranging from -1 to +1 ; values close to -1 mean that no vegetation or indicate the decrease in vegetation density, whereas those close to +1 indicate that the vegetation is in good growth and good health. These values were categorized into four classes of vegetation (dense vegetation, medium density vegetation, clear vegetation, and bare soil), and their area was calculated for comparison and vegetation cover dynamics over three years (1986-2000 and 2017).
Because the vegetation cover is very dynamic due to climate change and human activities, the value of NDVI is still found to be variable in many case studies. Therefore, it is important to assess the change in vegetation cover, in addition to detecting changes (Peng et al., 2012).

From the map of the NDVI we can see the progressive evolution of the vegetation of the forest of Belezma between 1986 and 2000 whereas during the period (2000-2017) the forest experienced a regressive evolution remarkable in the map in particular for dense vegetation. 


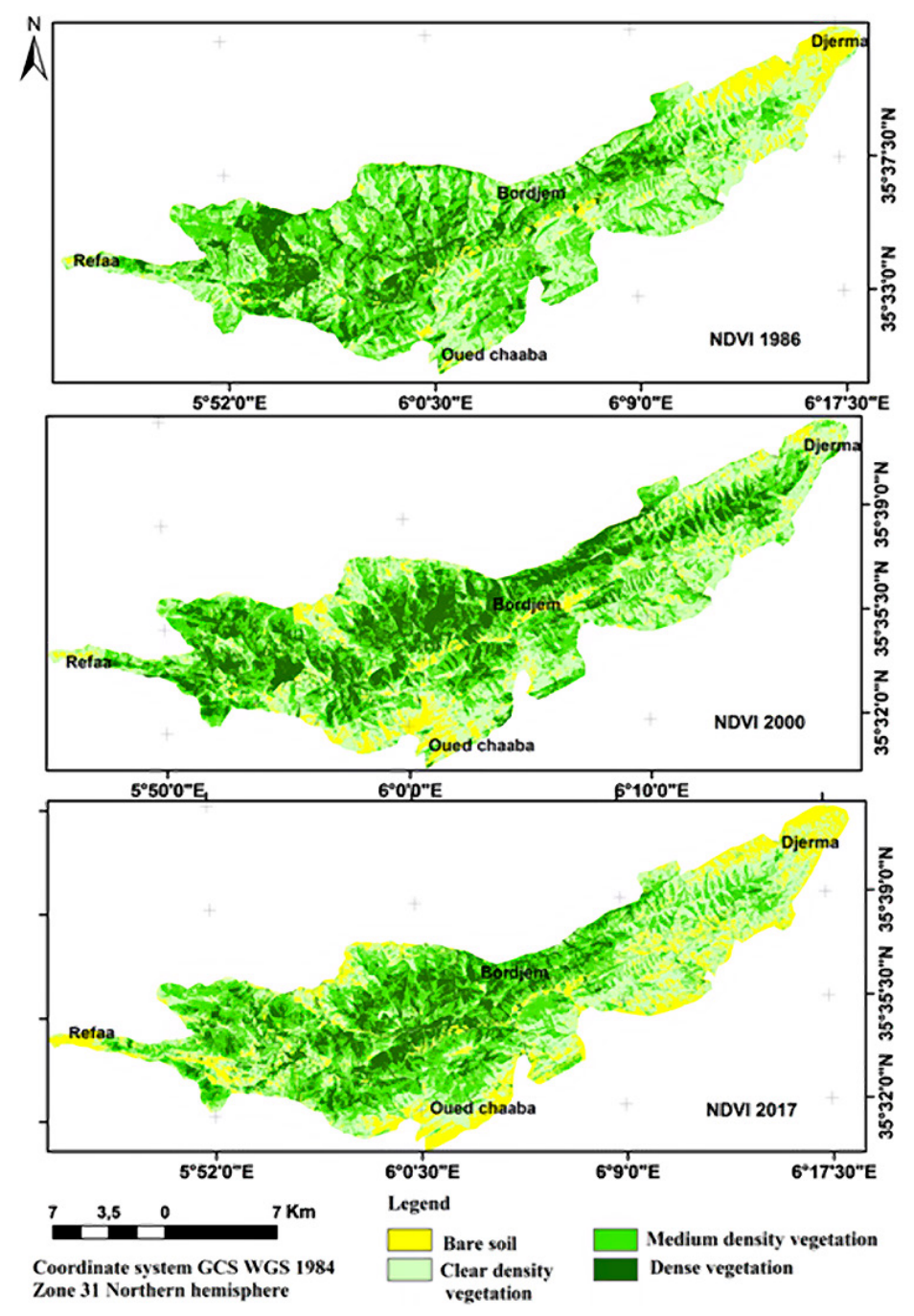

Figure 4. NDVI calculated from Landsat 5 TM (19-05-1986), Landsat 7 ETM + (15-04-2000) and Landsat 8 OLI-TIRS (22-04-2017) images

As it was said before that NDVI values that ranges from -1 to +1 , we can extract values for each class.

- In 1986 : Dense vegetation (from 0.5 to 0.7), Medium density vegetation (from 0.3 to 0.5 ), Clear density vegetation (from 0.1 to 0.3 ) and Bare soil (from -0.1 to 0.1).

- In 2000 : Dense vegetation (de 0.5 à 0.7 ), Medium density vegetation (de 0.3 à 0.5 ), Clear density vegetation (de 0.2 à 0.3 ) and Bare soil (-0.01 à 0.2).

- In 2017 : Dense vegetation (de 0.4 à 0.6 ), Medium density vegetation (de 0.3 à 0.4 ), Clear density vegetation (de 0.1 à 0.3 ) and Bare soil (o à 0.1 ).
From the analysis of the above data, profound changes have occurred over the last 31 years. The comparative analysis shows a gradual evolution of the dense vegetation from the year 1986 to 2000 this evolution amounts to regressing from the year 2000 to 2017. For the average density and the clear vegetation decreased in 1986-2000 but in 2000- 2017 have increased which confirms the degradation of the forest environment, especially the southern and southeastern part of the Belezma forest.

Table 1. Vegetation dynamics (1986-2017)

\begin{tabular}{|l|c|c|c|c|c|c|c|c|c|}
\hline \multirow{2}{*}{ Class I Surface } & 1986 & 2000 & 2017 & \multicolumn{2}{c|}{ Dynamic (1986-2000) } & \multicolumn{2}{c|}{ Dynamic (2000-2017) } & \multicolumn{2}{c|}{ Dynamic (1986-2017) } \\
\cline { 2 - 11 } & (ha) & (ha) & (ha) & (ha) & (\%) & (ha) & (\%) & (ha) & (\%) \\
\hline Dense vegetation & 4945,14 & 7664,49 & 4959,54 & 2719,35 & 7,91 & $-2704,95$ & $-7,86$ & 14,4 & 0,05 \\
\hline $\begin{array}{l}\text { Medium density } \\
\text { vegetation }\end{array}$ & 13579,38 & 12424,86 & 12577,85 & $-1154,52$ & $-3,72$ & 152,99 & 0,45 & $-1001,53$ & $-2,91$ \\
\hline $\begin{array}{l}\text { Clear density } \\
\text { vegetation }\end{array}$ & 13261,05 & 11646,72 & 11884,14 & $-1614,33$ & $-4,69$ & 237,42 & 0,69 & $-1376,91$ & -4 \\
\hline Bare soil & 2607,57 & 2657,07 & 4971,61 & 49,5 & 0,14 & 2314,54 & 6,73 & 2364,04 & 6,78 \\
\hline
\end{tabular}




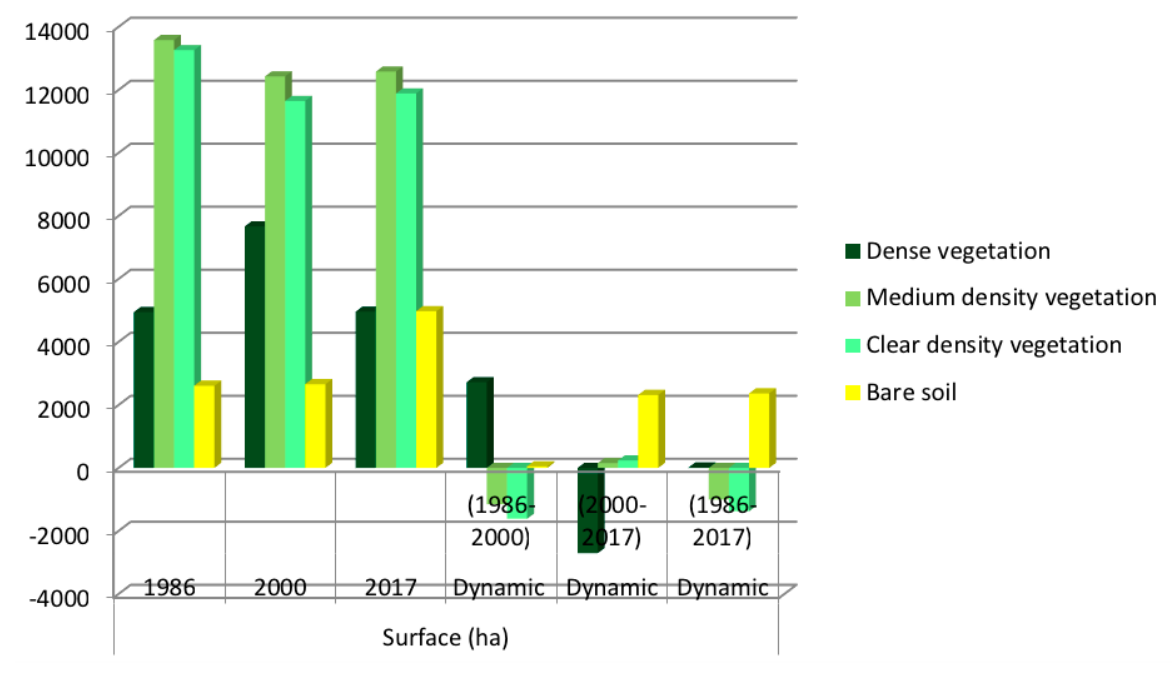

Figure 5. Diagram of class surfaces

\section{Result of the NDWI index}

From the results of the NDWI, it can be noticed that the years 1986 and 2017 are characterized with high values in large surfaces, which indicates the presence of the water in the vegetation that is to say high values of NDWI, unlike the year 2000 which shows less surfaces than other years.
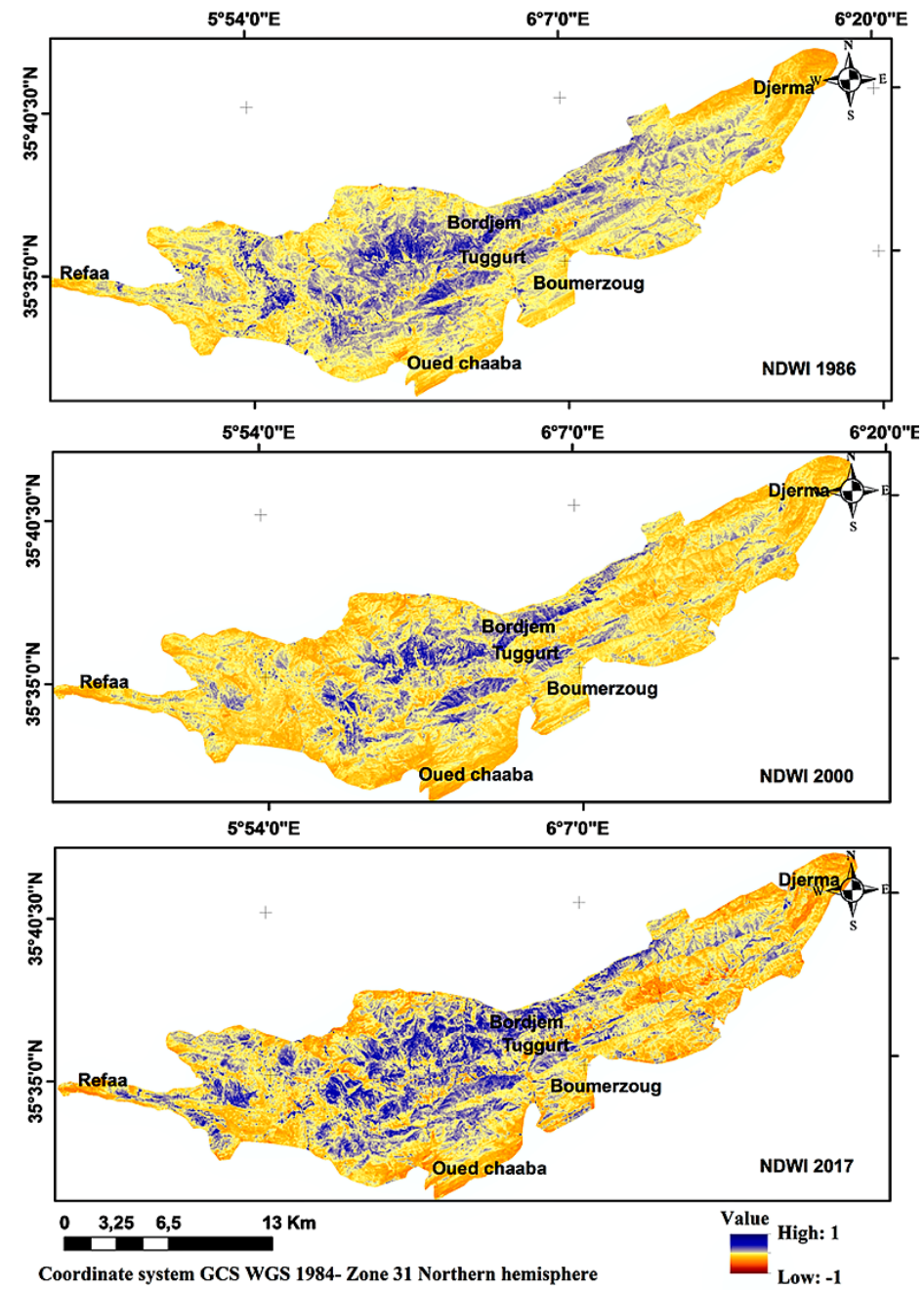

Figure 6. NDWI calculated from Landsat 5 TM (19-05-1986), Landsat 7 ETM + (15-04-2000) and Landsat 8 OLI-TIRS (22-04-2017) images 


\section{Calculation of temperatures and precipitation}

In this contribution the precipitation and temperatures of the corresponding years (1986-200o-2017) of the study were calculated in order to see the effect of climate on the vegetation cover. For this we have exploited the climatic data from the weather station of Ain Skhouna (Batna), which is located at an altitude of 821. 29 meters, because of absence of weather stations at the level of the Belezma forest we have been extrapolated from the Ain Skhouna (Batna) weather station.

Seltzer (1946), in his climate study of Algeria indicates that the average decrease in temperature is a function of altitude:

- Minimum temperature: decrease of $0.4{ }^{\circ} \mathrm{C}$ per $100 \mathrm{~m}$.

- Maximum temperature: decrease of $0.7^{\circ} \mathrm{C}$ per $100 \mathrm{~m}$.

According to (Seltzer, 1946), for a rise of $100 \mathrm{me}$ ters, the rainfall increases by $40 \mathrm{~mm}$, for the continent, and $80 \mathrm{~mm}$ for the coast.

The diagram (Fig.7) shows the rise of the average temperature during three years of observation (19862000-2017).
Comparing the NDWI results with precipitation during the three observation dates, we can confirm that the rainy year corresponds to a rise in the NDWI (this is the case for 1986 and 2017). While the year with lower precipitation totals is a low value for NDWI (the year 2000). Among all the temperature registration during this period, those of the year 2000 are the highest. High temperatures with low rainfall and low values of NDWI during the year 2000, confirms a drought, compared to other years of observation.

\section{Correlation of remote sensing indices with field data}

Points were selected according to the graduation of the vegetation cover. These points are divided into classes of dense vegetation, medium and clear vegetation. The NDWI levels were also taken at the same points by adding other field information such as altitude, slope, exposure, and so on. Also the list of species identified in each survey, after which we did a small analysis, which consists in determining the biological type of the species.

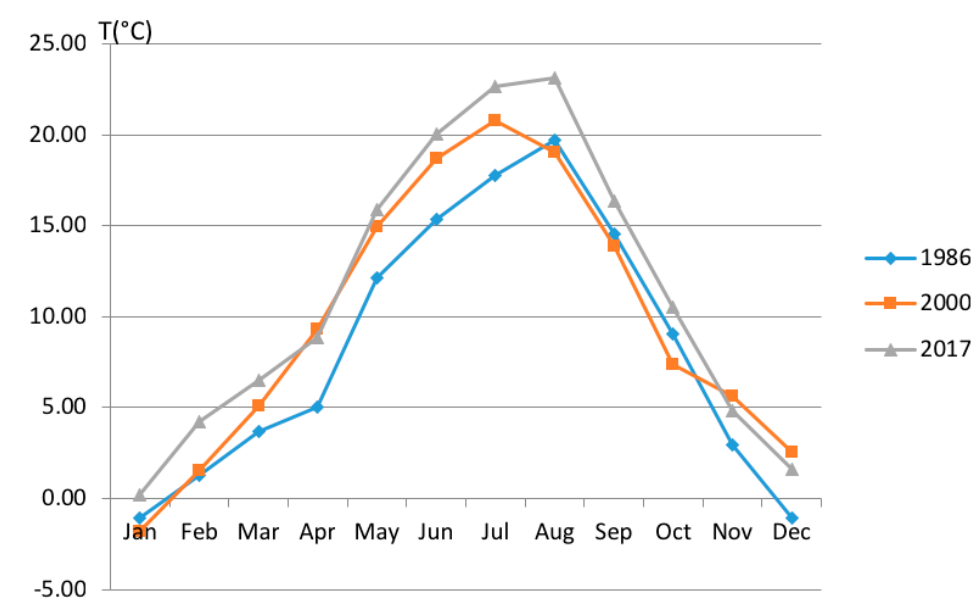

Figure 7. The average temperatures of the study area (Belezma) during the years 1986, 2000 and 2017.

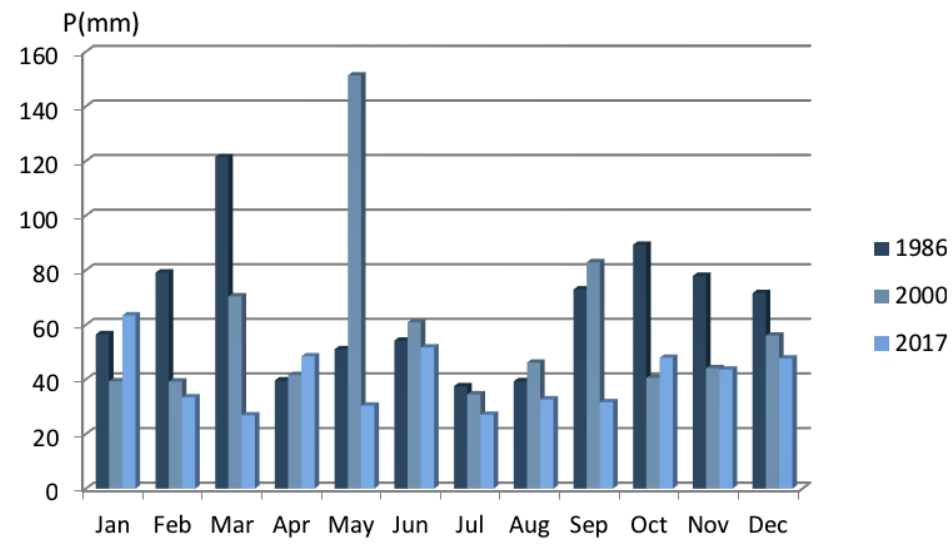

Figure 8. Precipitation of the study area (Belezma) during the years 1986, 2000 and 2017. 

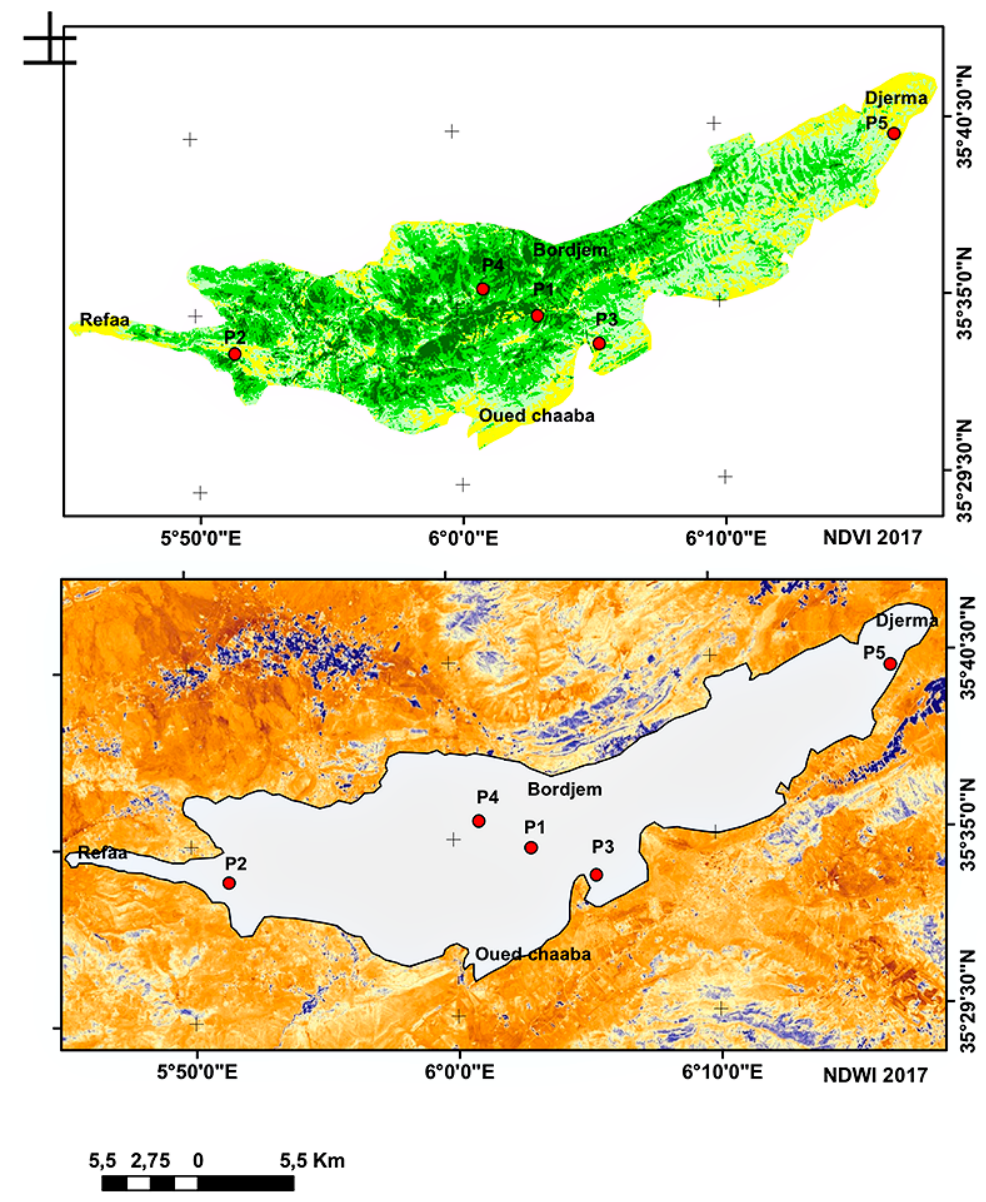

Coordinate system CGS WGS 1984 Datum WGS 1984

Survey points

Figure 9. Survey points map

We have selected some NDWI and NDVI map points for the year 2017 and confirmed with the field data to make the following table:

After correlation of remote sensing indices with field data, we can see that:

- The high values of the NDWI matches to the dense vegetation that is to say high values of NDVI close to 1 , this is the case of $\mathrm{P}_{1}$ Tuggurt and $\mathrm{P}_{2}$ Bordjem whose aspect is North and Northeast respectively.
- The average and low values of the NDWI correspond to the vegetation with medium density and clear vegetation; this is the case of the Refaa $\mathrm{P}_{2}$ station (southern aspect), the $\mathrm{P}_{3}$ Boumerzoug station (North exposure) and the Djerma $\mathrm{P}_{5}$ station (South aspect).

We also note that grazing is almost identified in all sampling points. Drought is not the only factor caus-

Table 2. Table of field data

\begin{tabular}{|l|l|l|l|l|l|l|l|l|l|l|}
\hline $\begin{array}{l}\text { Survey } \\
\text { point }\end{array}$ & Station & Longitude & Latitude & $\begin{array}{l}\text { Altitude } \\
(\mathrm{m})\end{array}$ & NDVI & NDWI & Slope & Aspect & $\begin{array}{l}\text { Litter } \\
\text { coverage }\end{array}$ & Pasture \\
\hline P1 & Tuggurt & $06^{\circ} 03^{\prime} 01,6^{\prime \prime}$ & $35^{\circ} 34^{\prime} 42,5^{\prime \prime}$ & 1468 & $\begin{array}{l}\text { Dense } \\
\text { vegetation }\end{array}$ & High & $>15 \%$ & North & $5-10 \%$ & Yes \\
\hline P2 & Refaa & $0^{\circ} 51^{\prime} 28,8^{\prime \prime}$ & $35^{\circ} 33^{\prime} 48,0^{\prime \prime}$ & 2028 & $\begin{array}{l}\text { Medium } \\
\text { density } \\
\text { vegetation }\end{array}$ & Medium & $<5 \%$ & South & $15 \%$ & Yes \\
\hline P3 & Boumerzoug & $06^{\circ} 05^{\prime} 21,6^{\prime \prime}$ & $35^{\circ} 33^{\prime} 45,4^{\prime \prime}$ & 1270 & $\begin{array}{l}\text { Clear density } \\
\text { vegetation }\end{array}$ & Low & $/$ & North & $0-5 \%$ & Yes \\
\hline P4 & Bordjem & $06^{\circ} 1^{\prime} 0,5^{\prime \prime}$ & $35^{\circ} 35^{\prime} 35,47^{\prime \prime}$ & 1760 & $\begin{array}{l}\text { Dense } \\
\text { vegetation }\end{array}$ & High & $>30 \%$ & North-Est & $5-10 \%$ & Yes \\
\hline P5 & Djerma & $06^{\circ} 16^{\prime} 52,07^{\prime \prime}$ & $35^{\circ} 40^{\prime} 3,32^{\prime \prime}$ & 1048 & $\begin{array}{l}\text { Clear density } \\
\text { vegetation }\end{array}$ & Medium & $/$ & South & Very low & $/$ \\
\hline
\end{tabular}


Table 3. Species identified on the ground

\begin{tabular}{|c|c|c|c|c|}
\hline \multicolumn{5}{|c|}{ Identified spicies } \\
\hline P1 & P2 & P3 & P4 & P5 \\
\hline $\begin{array}{l}\text { - Cedrus atlantica } \\
\text { - Cotoneaster } \\
\text { racemiflora } \\
\text { - Quercus ilex } \\
\text { - Juniperus oxycedrus } \\
\text { - Ornithogalum } \\
\text { umbellatum } \\
\text { - Silene italica } \\
\text { - Carduus nutans } \\
\text { - Galium aprine } \\
\text { - Coronila scorpioides } \\
\text { - Ampelodesma } \\
\text { mauritanicum } \\
\text { - Torilis nodosa } \\
\text { - Centaurea } \\
\text { tougourensis } \\
\text { - Ranunculus spicatus } \\
\text { - Ferula communis } \\
\text { - Asphodeline lutea } \\
\text { - Asphodelus } \\
\text { microcarpus } \\
\text { - Erinacea anthyllis } \\
\text { - Dactylis glomerata } \\
\text { - Malope malacoides } \\
\text { - Bellis sylvestris } \\
\text { - Aegilops triuncialis } \\
\text { - Poa bulbosa } \\
\text { - Lotus corniculatus } \\
\text { - Hyoseris radiata } \\
\text { - Thlaspi perfoliatum } \\
\text { - Hedypnois cretica } \\
\text { - Rumex tuberosus } \\
\text { - Calycotome spinosa }\end{array}$ & $\begin{array}{l}\text { - Cedrus atlantica } \\
\text { - Cotoneaster } \\
\text { racemiflora } \\
\text { - Quercus ilex } \\
\text { - Berberis hispanica } \\
\text { - Erinacea anthyllis } \\
\text { - Anacyclus clavatus } \\
\text { - Helianthemum } \\
\text { croceum } \\
\text { - Centaurea alba } \\
\text { - Thlaspi perfoliatum } \\
\text { - Bupleurum spinosum } \\
\text { - Bellis sylvestris } \\
\text { - Carex sp } \\
\text { - Satureja granatensis } \\
\text { - Teucrium polium } \\
\text { - Thymus ciliatus } \\
\text { - Asphodeline lutea } \\
\text { - Crupina vulgaris } \\
\text { - Xeranthemum } \\
\text { inapartium } \\
\text { - Cerastium } \\
\text { - gibraltaricum } \\
\text { - Sedum sediforme }\end{array}$ & $\begin{array}{l}\text { - Pinus halepensis } \\
\text { - Juniperus oxycedrus } \\
\text { - Juniperus phoenica } \\
\text { - Quercus ilex } \\
\text { - Olea europea } \\
\text { - Astragalus armatus } \\
\text { - Globularea alypum } \\
\text { - Stipa tenacissima } \\
\text { - Cistus monspeliensis } \\
\text { - Centaurea } \\
\text { - tougourensis } \\
\text { - Helianthemum } \\
\text { - Atrerum } \\
\text { - Erinactylis humilis } \\
\text { - Thymus sp } \\
\text { - Teucrium polium } \\
\text { - Paronychia argentea }\end{array}$ & $\begin{array}{l}\text { - Cedrus atlantica } \\
\text { - Juniperus oxycedrus } \\
\text { - Ranunculus spicatus } \\
\text { - Thlaspi perfoliatum } \\
\text { - Hyoseris radiata } \\
\text { - Medicago lupulina } \\
\text { - Geranium robertianum } \\
\text { - Knautia arvensis } \\
\text { - Asphodeline lutea } \\
\text { - Stellaria media } \\
\text { - Asphodelus } \\
\text { microcarpus }\end{array}$ & $\begin{array}{l}\text { - Juniperus oxycedrus } \\
\text { - Cuscuta sp } \\
\text { - Stipa tenacissima } \\
\text { - Rosmarinus officinalis } \\
\text { - Teucrium polium } \\
\text { - Teucrium pseudo- } \\
\text { - chamaepytis } \\
\text { - Brachypodum } \\
\text { distachyum } \\
\text { - Euphorbia helioscopia } \\
\text { - Sedum sediforme } \\
\text { - Paronychia argentea } \\
\text { - Micropus bombycinus } \\
\text { - Fumana sp }\end{array}$ \\
\hline
\end{tabular}

ing this degradation, there are others, such as: fire, overgrazing, phytosanitary problems (the processionary caterpillar), illegal cutting (Fig.10), etc.

Algeria is precisely one of the countries most affected by drought phenomena (rain less and less abundant) (Abd el guerfi, 2003). Located in a transition zone between temperate and subtropical regions, Algeria is highly sensitive to climate because of the great variability of seasonal and annual rainfall (Abd el guerfi, 2003).

For the last decades, a rise in temperatures and a decrease in rainfall over the whole country (Abd el guerfi, 2003). Drought by upsetting the equilibrium between living beings, favors the collapse of habitats, leading to the gradual disappearance of vegetation and animals, resulting in the installation of deserts (Abd el guerfi, 2003).

The impact of drought on the forest also takes other forms. Thus, in addition to the alteration of natural balances, the recrudescence of fires and the reduction of terrestrial and piscicultural fauna, the weakening of trees encourages the proliferation of parasitic attacks and reduces the possibilities of renewal of the forest (Narjisse et al., 2001).

The Belezma forest underwent significant modifications during this study period (1989-2017), a remarkable regressive evolution of the forest cover was noticed, especially between 2000 and 2017 located mainly in the South and South-East of the forest, these degraded areas are the most vulnerable to desertification.

According to Boudy (1952), the action of animals is represented, above all, by that of cattle grazing in the forest. This action is almost always harmful and constitutes the main factor of destruction of the forested state. The excessive grazing transforms most often the forest in a form of regressive vegetation, such as scrub, maquis, where the trees disappeared and where there are only shrubs of lesser value (Boudy, 1952). 

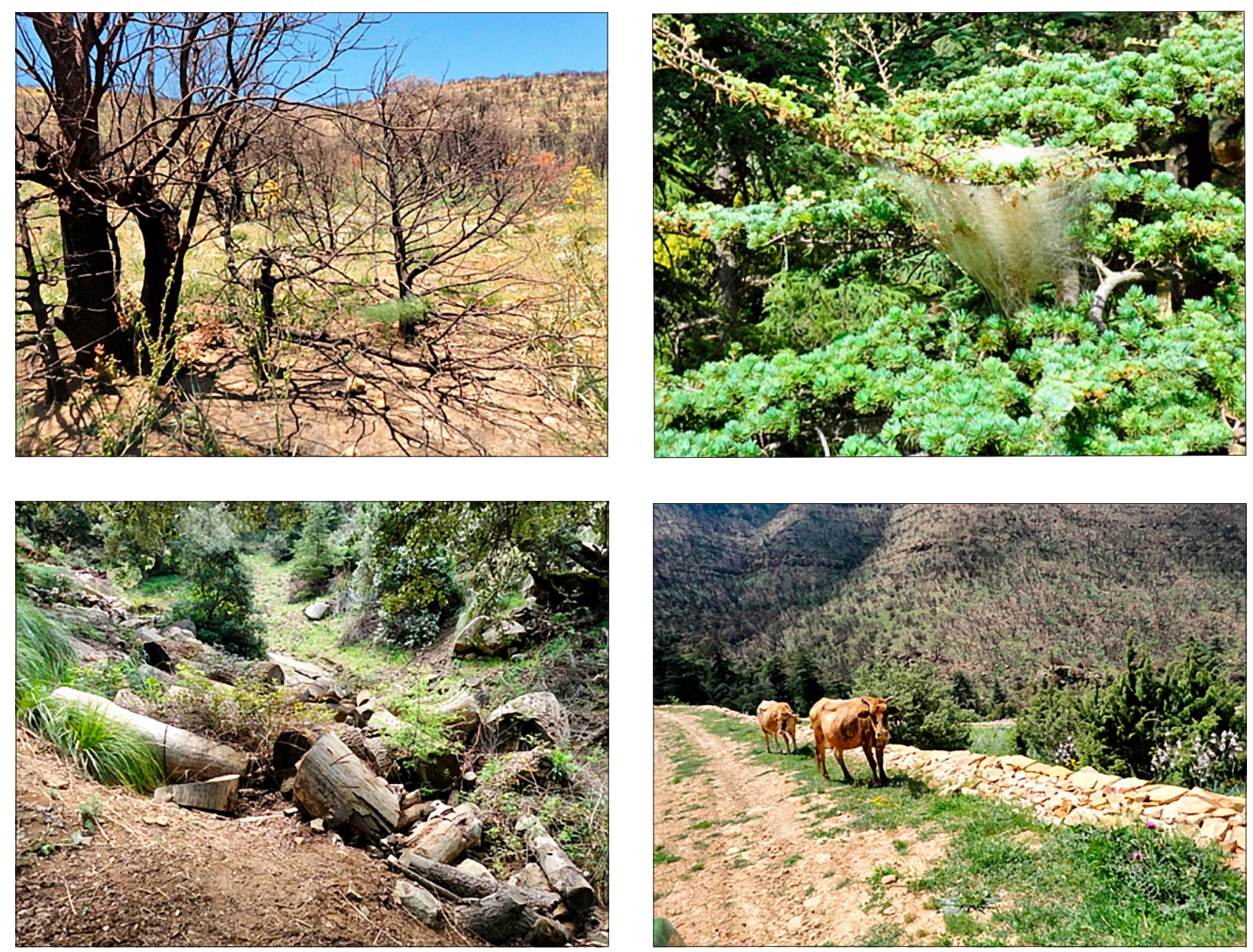

Figure 10. Degradation factors of the Belezma forest

\section{Conclusion}

In remote sensing applications, changes are considered as alterations of surface components with varying rates. Information on changes in land cover and land use is important because of their practical use in a variety of applications, including deforestation, damage assessment, disaster monitoring, urban expansion, planning and land management (Hussain et al., 2013).
The use of remote sensing and GIS allowed us to understand the dynamics of land use. Remote sensing data analysis and field data reveal a regressive change in the Belezma Forest during the period (1986-2017). Declining rainfall and drought in recent decades are among the main factors in the degradation of this forest environment with other factors; overgrazing, logging, fire, etc. Of which, reduced vegetation cover plays an important role in the process of desertification.

\section{References}

Abdelguerfi, A. (2003). Mises en cuvre des mesures générales pourla conservation in situ et ex situ et l'utilisation durable de la biodiversité en Algérie: Bilans des expertises, [Implementation of general measures for in situ and ex situ conservation and the sustainable use of biodiversity in Algeria: Appraisal reports]. FEM/PNUD Projet ALG/97/G31 Plan d'Action et Stratégie Nationale sur la Biodiversité TOME III. 145 p.
Abdessemed, K. (1981). Le cèdre de l'Atlas (Cedrus atlantica. Manetti) dans les massifs de l'Aures et du Belezma: étude phytosociologique, problèmes de conservation et d'aménagement. [The cedar of the Atlas (Cedrus atlantica, Mannetti) in the massifs of Aures and Belezma- Phytosociological study and problem of conservation and development]. (Doctoral dissertation) Marseille: Fac. St. Jérôme, 199 p. 
Bensaid, A. (2006). SIG et télédétection pour l'étude de l'ensablement dans une zone aride: Le cas de la wilaya de Naàma (Algérie), [GIS and remote sensing for the study of silting in an arid zone: The case of the wilaya of Naama], (Doctoral dissertation), Algérie: Université Essenia Oran, 325p.

Boudy, P. (1952). Guide du forestier en Afrique du Nord, [North Africa Forestry Guide]. Paris: La maison rustique, 505p.

Chenouf, N., Abdelguerfi, A., Chehat, F., Ferrah, A., \& Yahiaoui, S. (2009). Quatrième rapport national sur la mise en ouvre de la convention sur la diversité biologique au niveau national. [Fourth National Report on the Implementation of the Convention on Biological Diversity at National Level]. Algérie: Ministère de l'aménagement du territoire, de l'environnement et du tourisme. 121p.

Deshayes, M., \& Maurel, P. (1991). L'image spatiale et son contenu. [The spatial image and its content]. Options Méditerranéennes: Série A. Séminaires Méditerranéens (4), 11-20; Montpellier: Ciheam

Gao, B. C. (1996). NDWI-A normalized difference water index for remote sensing of vegetation liquid water from space. Remote sensing of environment, 58(3), 257-266.

Gerard, B., Richard, E., Delphine, F., \& Anne-therese, H. (2014). La télédétection: Un outil pour le suivi et l'évaluation de la désertification. Comité Scientifique Français de la Désertification. [Remote sensing: A tool for the monitoring and evaluation of desertification. French Scientific Committee of Desertification]. France.

Gounot, M. (1969). Méthode d'étude quantitative de la végétation. [Method of quantitative study of vegetation]. Paris, France: Masson. 314 p.

Hussain, M., Chen, D., Cheng, A., Wei, H., \& Stanley, D. (2013). Change detection from remotely sensed images: From pixel-based to object-based approaches. ISPRS Journal of photogrammetry and remote sensing, 80, 91-106.
Narjisse, H., M'hirit, O., Askarn, O., Benzyane, M., \& El Omerani, A. (2001). Le couvert végétal marocain: etat de dégradation, acquis et perspectives en matière de conservation et de mise en valeur [Moroccan vegetation cover: state of degradation, achievements and prospects in terms of conservation and enhancement]. Revue HTE, (119), 25-29.

Peng, J., Liu, Y., Shen, H., Han, Y., \& Pan, Y. (2012). Vegetation coverage change and associated driving forces in mountain areas of Northwestern Yunnan, China using RS and GIS. Environmental monitoring and assessment, 184(8), 4787-4798.

Quezel, P., \& Barbero, M. (1990). Les forêts méditerranéennes problèmes posés par leur signification historique, écologique et leur conservation. [Mediterranean forests problems posed by their historical, ecological and conservation significance]. Acta Botánica Malacitana, 15, 145-178.

Sahli, M. (2004). Environnement, aménagement et stratégie de développement de protection de la nature. Cas de Parc National du Belezma (Monts de Batna, Algérie). [Environment, planning and development strategy for nature protection. Case of Belezma National Park (Batna Mountains, Algeria)]. (Doctoral dissertation) Univ. Mentouri-Constantine. $244 \mathrm{p}$.

Seltzer, P. (1946). Le climat de l'Algérie. [The climate of Algeria]. Algérie: Travaux de l'Institut de Météorologie et de Physique du Globe de l'Algérie. 219 pp.

Stour, L., \& Agoumi, A. (2008). Sécheresse climatique au Maroc durant les dernières décennies. Hydroécologie appliquée, 16, 215-232.

Tidjani, A. A., Ozer, A., \& Karimoune, S. (2009). Apports de la télédétection dans l'étude de la dynamique environnementale de la région de Tchago (nord-ouest de Gouré, Niger). Geo-Eco-Trop, 33, 69-8o.

\section{Other sources}

USGS earth explorer : https://earthexplorer.usgs.gov/ 